\title{
A Wind of Change
}

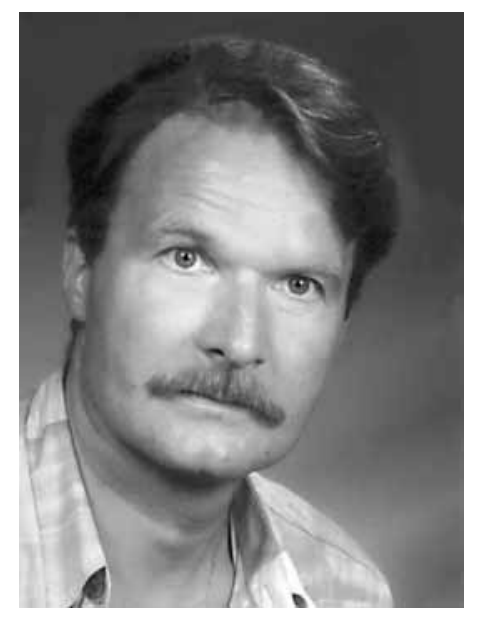

When Professor Herzog asked me whether I would be interested to succeed him as Editor of Respiration I accepted this honorable offer without hesitation. Respiration is a well-established international journal in the field of respiratory medicine. During one full year I had the privilege to learn the trade, editing the journal together with Professor Herzog whose help was invaluable to prepare me for the job. With his over 30 years of editorship he has accumulated a wealth of experience and has also witnessed the tremendous changes in publishing style during his time. For all his input and the preparation of his succession I am deeply grateful to him and wish him all the best for his retirement.

Several challenges face Respiration in 1998. In general, the market for published medical journals worldwide has become tougher. In the field of respiratory medicine the extremely successful emergence of the European Respiratory Journal represents serious competition to other journals including the leading US publications. Respiration continues to do well, but, in my opinion, has had the disadvantage of being almost exclusively institution-based for its subscriptions; the rates for personal subscriptions were too high. In order to remain competitive, however, a journal also needs many individual subscribers who will guarantee continued institutional interest. For this reason the rates for individual subscriptions have been cut by $70 \%$ to SFr. 98.00 per annum (1 volume with 6 issues)!

As from 1998 the Editorial Board will consist of an Editor-in-Chief who will be supported by several Associate Editors and by a renowned team of individual Board Members. Many new sections will be introduced. Regular editorials will comment key publications, original articles will be grouped into clinical and basic science investigations, as well as case reports or case series. Hot topics can be submitted as rapid communications, which will be processed within 4 weeks of receipt of the manuscript. It will, however, remain at the discretion of the Editorial Board to decide whether an article merits the fast tract or will be reviewed as a normal manuscript.

Another important new feature will be the thematic review series, covering one topic in all its major aspects for 1 year with one article appearing in each of the six issues of one volume. 1998 will be dedicated to tuberculosis. The illustration of the journal cover will reflect the thematic review topic and therefore run for 1 year. To add further variety, additional sections will appear: the 'Eye Catcher' is a full page illustration of a case with emphasis on optical presentation; the sections: 'What is Your Diagnosis', 'Clinicopathological Conference', and 'Technical Notes' are self-explanatory. 'Letters to the Editors' are

\section{KARGER}

Fax + 41613061234

E-Mail karger@karger.ch www. karger.com
두 1998 S. Karger AG, Basel

This article is also accessible online at: http://BioMedNet.com/karger 
encouraged as they often give valuable additional information and stimulate debate. An extended congress calendar is added.

Reviews other than the ones in the thematic review series will also appear; they will either be solicited or submitted spontaneously by authors who wish to contribute a review article in the area of their expertise. Acceptance of all these articles is also subject to approval by the Editorial Board.

Respiration has followed the trend of many leading journals and is now also available by online subscription on the internet at http://www.karger.ch/online. The online subscription is available in addition to the printed edition only. The impact of electronic publications on printed editions is a hotly discussed topic. Some people claim that most of the hard copy medical journals will eventually disappear. Similar opinions were voiced with the advent of television which should have heralded the end of movie houses and books. My personal belief is that printed medical journals will survive, but that people will become more selective as to what journals they want to subscribe to. For the rest they will browse through the abstracts on the net and download (= pay!) specific articles they want to have as hard copies. So, I am fairly confident that quality medical journals will continue to thrive in print.

Finally, who is Respiration's target audience? Readers will find that the emphasis will remain on clinical aspects of thoracic medicine, but basic science will continue to play an important part. More than ever the journal will be an international publication, which is totally independent and should attract readers and contributions from all over the world. In the future careful selection of adequate global representation of the Editorial Board will reflect this position.

My vision for Respiration is to guarantee its continued success by implementing all above-mentioned changes. The publishing house, S. Karger AG, with its reputation of high quality will be a key factor in this endeavour.

Basel, December 1997

C.T. Bolliger 